[Agr. Biol. Chem., Vol. 29, No. 10, p. 943 948, 1965]

\title{
Studies on the Utilization of Hydrocarbons by Microorganisms
}

\section{Part VI. Screening of Aromatic Hydrocarbon-Assimilating Microorganisms and Cumic Acid Formation from p-Cymene}

\author{
By Koichi Yamada, Sadayuki Horiguchi and Joji Takahashi \\ Department of Agricultural Chemistry, Faculty of Agriculture, The University of Tokyo, Tokyo
}

Received June 7, 1965

\begin{abstract}
During the course of an investigation of the microbial assimilation of aromatic hydrocarbons, several strains were found to produce a large amount of cumic acid from p-cymene.

Five strains, S449B1, B2, B3, B4 and B6, were isolated from soil with the aromatic hydrocarbon substrates. They all assimilated both $p$-cymene and cumene. The strain S449B3 grew also on p-xylene, and S449B6 on p-xylene, toluene, and ethylbenzene.

They were all shown to be capable of producing an ultraviolet-absorbing substance from $p$-cymene. This substance was isolated in crystalline form and identified as cumic acid by infrared absorption spectrum and other observations.

The superior strain, S449B6, produced the acid as much as $1000 \mathrm{mg} / \mathrm{l}$ in shaking culture at $30^{\circ} \mathrm{C}$ after 24 hours. The yields were increased up to approximately $1700 \mathrm{mg} / \mathrm{l}$ after further investigations. Addition of calcium carbonate and considerable agitation were favorable conditions for the acid production.

The taxonomical studies of these strains were carried out, and they were all identified as closely resembling Pseudomonas desmolytica.
\end{abstract}

\section{INTRODUCTION}

In view of the industrial importance, increasing interest is being shown in the utilization of various hydrocarbons by microorganisms. Especially the fetmentative production of amino acid and cells from n-alkane has been reported by several groups of workers. ${ }^{1 \sim 4}$

In this point of view, previous investigations of aromatic hydrocarbons have dealt almost exclusively with the formation of salicilic acid from naphthalene. ${ }^{5}$ While, in recent years, a good deal of attention has been

1) K. Yamada, J. Takahashi, K. Kobayashi and Y. Imada, This Journal, 27, 390 (1963).

2) K. Yamada, J. Takahashi and K. Kobayashi, This Journal, 27, 773 (1963).

3) A. Champagnat, Ch. Vernet, B. Laine and J. Filose, the Sixth W.P.C. (1963).

4) J. Takahashi, K. Kobayashi, Y. Imada and K. Yamada, This Journnl, 27, 836 (1963).

5) P. Hsler, Biotech. Bioeng., 5, 243 (1963). paid for the microbial transformation of organic compounds.

Therefore, this work was initiated as a part of an extensive program on the microbial assimilation and transformation of aromatic hydrocarbons. In this paper, identification of newly isolated microorganisms, microbial formation of cumic acid from $p$-cymene and some aspects of their cultural conditions are presented.

\section{MATERIALS AND METHODS}

Microorganisms. Five microorganisms, S449B1, $B 2, B 3, B 4$ and B6, were isolated from soil by a screening procedure with aromatic hydrocarbon substrates.

Diagnostic tests for morphological studies were carried out according to the "Manual of Microbiological Methods," 1957, Society of American Bacteriologists, and referred to the "Bergey's Manual 
of Determinative Bacteriology," 7th Ed., 1957.

Medium. The medium contained, per liter, $4.0 \mathrm{~g}$

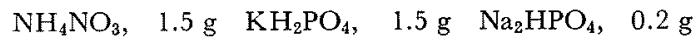
$\mathrm{MgSO}_{4} \cdot 7 \mathrm{H}_{2} \mathrm{O}, 0.05 \mathrm{~g} \mathrm{FeSO}_{4} \cdot 7 \mathrm{H}_{2} \mathrm{O}, 0.002 \mathrm{~g} \mathrm{MnSO}_{4}$. $4 \mathrm{H}_{2} \mathrm{O}, 0.01 \mathrm{~g} \mathrm{CaCl} 2 \cdot 2 \mathrm{H}_{2} \mathrm{O}, 0.5 \mathrm{~g}$ yeast extract. A five hundred milli-liter-flask, containing $50 \mathrm{ml}$ of the medium, was autoclaved at $110^{\circ} \mathrm{C}$ for 10 minutes. Before cultivation, $0.5 \mathrm{ml}$ of sterile hydrocarbon was added to the medium in the flask.

Cultivation. When cultural conditions were tested, $1.5 \mathrm{ml}$ of cell suspension, grown on $p$-cymeneagar-slant for 2 days, was inoculated into $50 \mathrm{ml}$ of the medium. The medium was incubated at $30^{\circ} \mathrm{C}$ on reciprocal shaker for 1 to 7 days.

Hydrocarbons. All of the hydrocarbons (toluene, $p$-xylene, ethylbenzene, $m \& p$-diethylbenzene, cumene and $p$-cymene) were obtained from Tokyo Chemical Industry Co., Ltd. and were used without further purification.

In isolation procedures, hydrocarbon mixture, containing equal volume of the all hydrocarbons listed above, was used as a sole carbon source.

For hydrocarbon assimilation tests, $n$-alkane mixture, containing equal volume of $n$-dodecane and $n$-hexadecane, was employed.

Table I. Solvent Systems and Developing REAGENTS FOR THE DETECTION OF METABOLIC PRODUCTS$$
\text { Solvent }
$$

Reagent

1. $\left(\mathrm{NH}_{4}\right)_{2} \mathrm{CO}_{3}-\mathrm{NH}_{4} \mathrm{OH}$ -n-Butanol*

M. R.**

Diazotized Benzidine*k* U.V.-Ray Irradiation

$$
\begin{aligned}
& \quad \text { Metabolic } \\
& \quad \text { Product } \\
& \text { Organic Acid } \\
& \text { Phenolic } \\
& \text { compound } \\
& \text { U.V.-Ray- } \\
& \text { absorbing } \\
& \text { compound }
\end{aligned}
$$

2. n-Butanol Ninhydrin :Acetic acid Amino acid

Water

$$
\text { (4:1:2) }
$$

* $n$ Butanol was saturated with ammonia/ammonium car bonate buffer ( $1.5 \mathrm{~N}$ with respect to each). ${ }^{6}$ )

** A mixture of 5 parts of $0.1 \%$ alcoholic methyl red solution with 10 parts of $\mathrm{M} / 15$ phosphate buffer solution $\mathrm{pH} 7.0$.

*** A: Five grams of benzidine was dissolved in $14 \mathrm{ml}$ of concentrated hydrochloric acid and the solution was filled up to 11 with water.

$B:$ Ten per cent sodium nitrite solution in water The solutions $A$ and $B$ were mixed at equal volume before spraying.

6) M.E. Fewster and D.A. Hall, Nature Lond., 168, 78 (1951).
Paper Chromatography. Paper chromatography was employed for detection of metabolic products. Solvent systems used are listed in Table I. The spots were visualized by ultraviolet-ray irradiation and/or the spraying of the developing reagents (Table I). Tôyô filter paper No. 50 was used.

Acid. Cumic acid, produced in cultural broth, was extracted by equal volume of ether. The ether solution was titrated by $1 / 20 \mathrm{~N}-\mathrm{NaOH}$, then amount of the acid produced was calculated from the titration value.

\section{RESULTS AND DISCUSSION}

Isolation of Microorganisms from Soil.

Accumulation cultures with $1 \mathrm{~g}$ of a soil sample and $50 \mathrm{ml}$ of the medium were carried out at $30^{\circ} \mathrm{C}$ for 4 to 7 days. Organisms, isolated after second accumulation culture, were tested for their abilities to utilize the individual hydrocarbons. Results are shown in Table II.

TABLE II. ASSIMILATION OF HYDROCARBONS BY ISOLATED BACTERIA

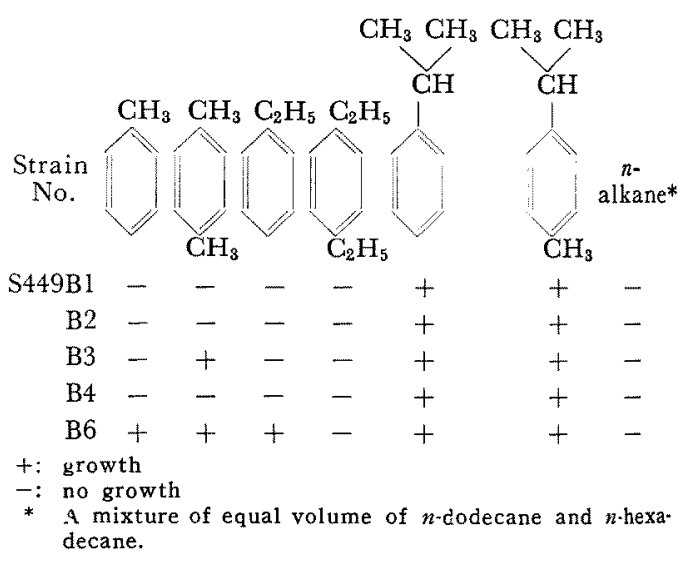

Sixty-eight enriched cultures were screened but only five microorganisms (S449B1, B2, B3, $\mathrm{B} 4$ and $\mathrm{B} 6$ ) were isolated. It seems to be very important reason for poor isolation that toluene was rather toxic for growth of some microorganisms.

Taxonomical Studies of Isolated Microorganisms.

The results of taxonomical studies are shown in Fig. 1 and Table III, together with the com- 


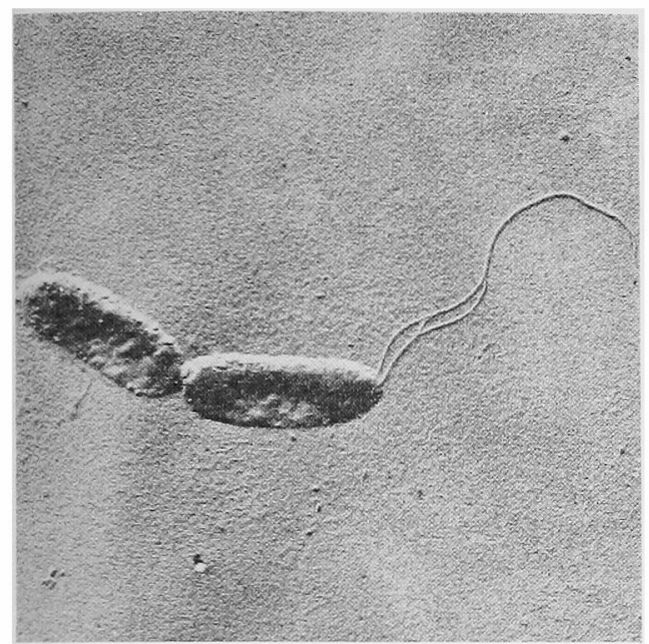

FIG. 1. Electron Microscopic Photograph of Strain S449B3.

parable descriptions in the Bergey's Manual, 7th Ed. The morphological characteristics of the all strains were exactly the same to each other.

From these results, it was concluded that all the strains were very closely resemblying Pseudomonas desmolytica.

It was reported by Tabak, Chambers and $\mathrm{Kabler}^{7)}$ that pseudomonads readily adapted to aromatic derivatives. However, it could not be determined whether the newly isolated strains weae adaptive or not.

Determination of Metabolic Products.

Each strain was cultivated on the individual hydrocarbons. After 24, 63 and 193 hours, the cultural broth was submitted to the paper chromatography.

From p-cymene substrates, methyl-red positive and ultraviolet-absorbing spot was detected from the broth of all 5 strains (Solvent 1).

This substance was isolated in crystalline form from the cultural broth of the strain S449B6 by extraction with ether and was recrystallized from water. The chemical

7) H. H. Tabak, C. W. Chambers and P. W. Kabler, J. Bacteriol., 87, 910 (1964).
TABle III. Descriptive Chart of the Isolated MICROORGANISMS

$\begin{array}{cc}\begin{array}{c}\text { Pseudomonas } \\ \text { desmolytica }\end{array} & \text { S449B1, B2, B3, } \\ \text { B4 and B6 }\end{array}$

Morphological Rods, 0.7 to 0.8 by Rods, 0.6 to 0.9 by characteristics 2.0 to $3.0 \mu, \quad 1.5$ to $2.0 \mu$, occurring singly occurring singly and in pairs. and in pairs. Motile, with 1 to 1 to 6 polar 5 polar flagella. flagella. GramGram-negative. negative.

Gelatine Circular, gray to Irregular, gray to colonies buff. Smooth, buff. Rough, dull, glistening, entire. undulate. Raised or Umbonate. umbonate.

Gelatin stab No liquefaction. No liquefaction.

Agar colonies Circular or amoe- Circular, convex, boid, whitish, flat smooth, transor convex, smooth, lucent or opaque, translucent to glistening, pale opaque, entire. yellowish green

\begin{tabular}{|c|c|c|}
\hline Agar slant & $\begin{array}{l}\text { Filiform, pale } \\
\text { buff, raised, } \\
\text { smooth. undulate. }\end{array}$ & $\begin{array}{l}\text { Filiform, pale } \\
\text { yellowish green, } \\
\text { raised, smooth, } \\
\text { undulate. }\end{array}$ \\
\hline Broth & Turbid. & Turbid. \\
\hline $\begin{array}{l}\text { Action on } \\
\text { nitrate }\end{array}$ & $\begin{array}{l}\text { Nitrites often } \\
\text { produced. }\end{array}$ & Nitrites produced. \\
\hline $\begin{array}{l}\text { Hydrolysis of } \\
\text { starch }\end{array}$ & Negative. & Negative. \\
\hline $\begin{array}{l}\text { Cleavage of } \\
\text { sugar }\end{array}$ & $\begin{array}{l}\text { Acid usually pro- } \\
\text { duced from } \\
\text { glucose. }\end{array}$ & $\begin{array}{l}\text { Acid produced } \\
\text { only from } \\
\text { glucose. }\end{array}$ \\
\hline Free oxygen & $\begin{array}{l}\text { Aerobic, facul- } \\
\text { tative. }\end{array}$ & Aerobic. \\
\hline Temperature & Grows at $35^{\circ} \mathrm{C}$. & $\begin{array}{l}\text { Grows at } 35^{\circ} \text { and } \\
37^{\circ} \mathrm{C} \text {. }\end{array}$ \\
\hline
\end{tabular}

Source Isolated from soil. Isolated from soil.

characteristics of the crystal were compared with those of the authentic cumic acid.

As shown in Figs. 2 and 3, the samples had identical infrared absorption spectra, and m.p. 118 to $118.5^{\circ} \mathrm{C}$.

Production of Cumic Acid by the Organisms.

The amounts of the acid formed are shown in Table IV. Maximum amount of the acid formed was observed with strain S449B6, which was employed for the following experiments as a test organism.

Some Aspects of Cumic Acid Formation by Strain S449B6.

The course of the cultivation of the strain 


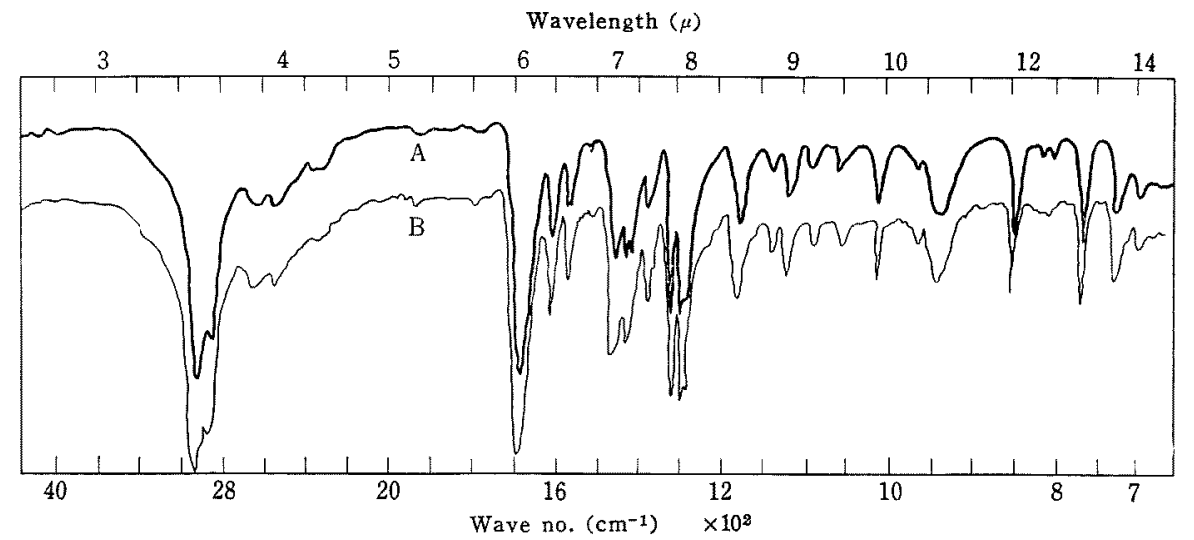

Fig. 2. Infrared Absorption Spectra of the Product.

A; Product B; Authentic cumic acid

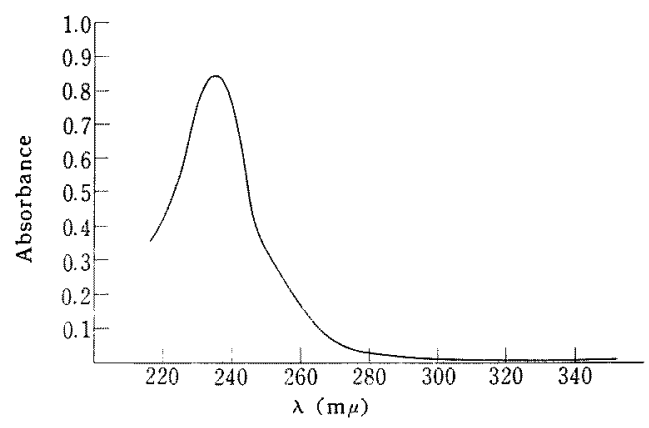

FIG. 3. Ultraviolet Absorption Spectra of the Product.

$1.2 \mathrm{mg}$ of the sample was dissolved in $100 \mathrm{ml}$ of $0.01 \mathrm{~N} \cdot \mathrm{NaOH}$.

TABLE IV. ProduCtion OF CUMIC ACID BY THE ORGANISMS (mg/l)

\begin{tabular}{rcrr} 
& \multicolumn{3}{c}{ Time (hr. } \\
Strain No. & 22 & 73 & 116 \\
S449B1 & 887 & 888 & 798 \\
B2 & 917 & 934 & 832 \\
B3 & 927 & 874 & 824 \\
B4 & 284 & 251 & 257 \\
B6 & 974 & 965 & 905
\end{tabular}

S449B6 was followed. The results are shown in Fig. 4. It is clear that maximum productions of both the acid and the cells were obtained at 15 hours after inoculation, when $\mathrm{pH}$ value of the cultural broth was minimal 4.6 .

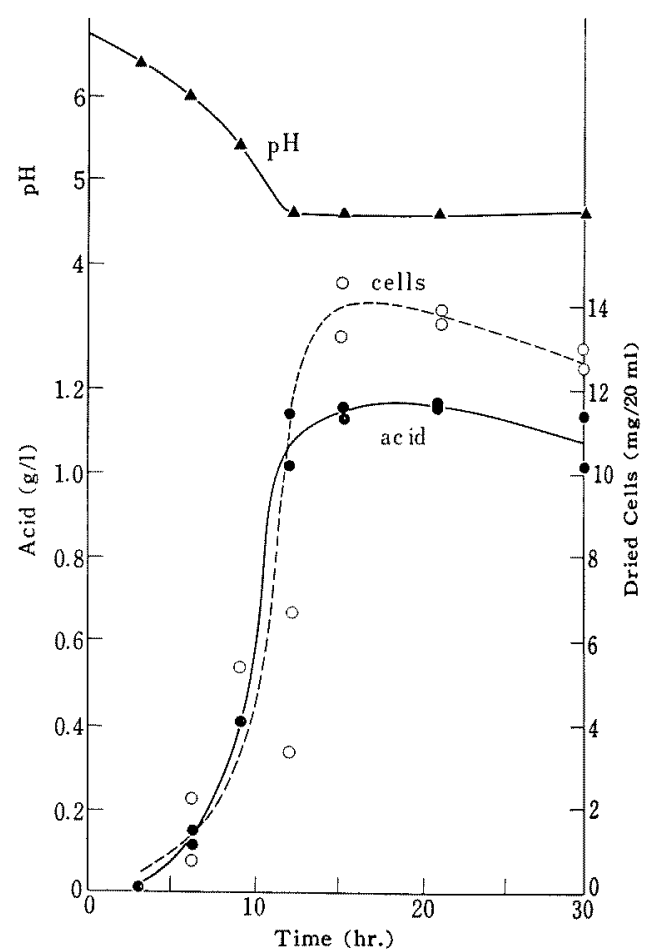

Fig. 4. Time Course of the Acid Production.

So it seems to be very likely that the control of the $\mathrm{pH}$ value results in higher yield of the acid as shown in Fig. 5.

Then the effect of $p$-cymene concentration 
on the acid production was tested (Fig. 6). Although the highest yield of the acid was obtained from $10 \% p$-cymene, the most effective conversion of $p$-cymene to the acid was observed at the concentration of $0.5 \%$.

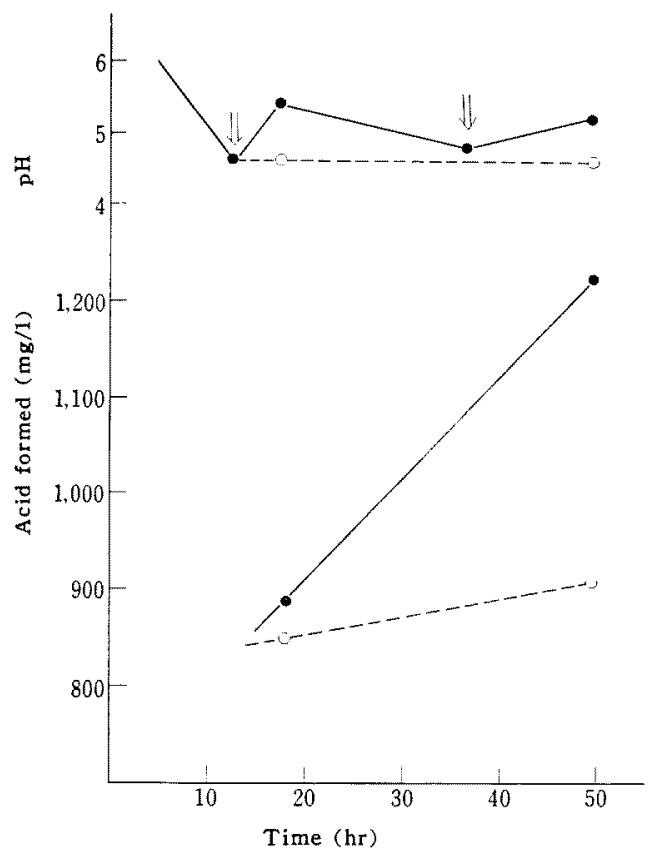

FIG. 5. Effect of $\mathrm{CaCO}_{3}$ on the Acid Production.
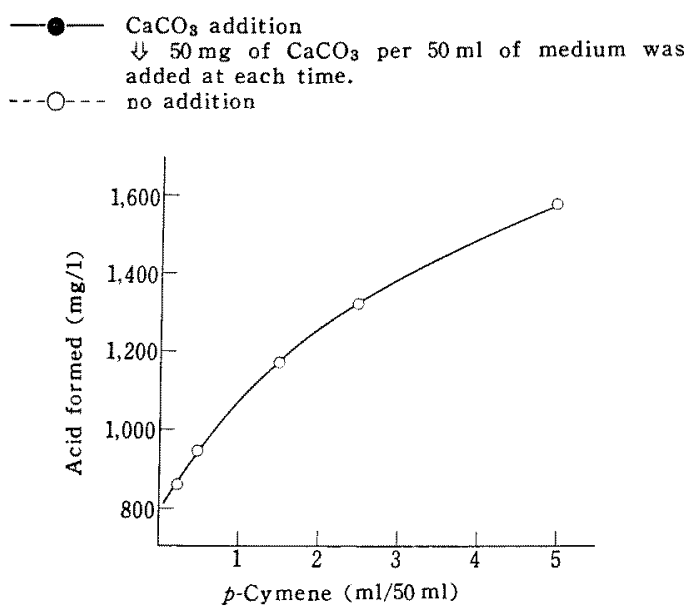

FIG. 6. Effect of $p$-Cymene Concentration on the Acid Production.
Because the acid formation is oxidative process, aeration will be indispensable factor. So the relationship between the volume of the medium and the amount of the acid formed was investigated in the range of the volume from $25 \mathrm{ml}$ to $200 \mathrm{ml}$ per $500 \mathrm{ml}$-flask.

The results were obscure as shown in Table $\mathrm{V}$. But as shown in Table VI the agitation seemed to be more strictly effective. It was concluded that the acid formed at 160 reciprocation per minute (Re. P.M.) was some $30 \%$ higher than at 132 Re. P.M.

Fig. 7 shows that the acid formation was not significantly effected at either $26.5^{\circ}, 30^{\circ}$ or $37^{\circ} \mathrm{C}$.

TABLE V. EFFECT OF VOLUME OF MEDIUM ON THE ACID PRODUCTION (mg/l)

\begin{tabular}{ccc} 
Medium & \multicolumn{2}{c}{ Time (hr.) } \\
(ml/500 ml flask) & 25 & 117 \\
25 & 970 & 1060 \\
50 & 939 & 1070 \\
100 & 970 & 977 \\
200 & 844 & 892
\end{tabular}

TABle VI. EFFect of AgItation ON THE ACID PRODUCTION

$\begin{array}{ccc}\begin{array}{c}\text { Agitation } \\ \text { (Recip. P.M.*) }\end{array} & \begin{array}{c}\text { Exp. } \\ \text { No. }\end{array} & \begin{array}{c}\text { Acid found } \\ \text { (mg/1) }\end{array} \\ 132 & 1 & 1250 \\ & 2 & 1130 \\ 160 & 1 & 1680 \\ & 2 & 1650\end{array}$

Reciprocation per minute

The cultivation was carried out at $37^{\circ} \mathrm{C}$

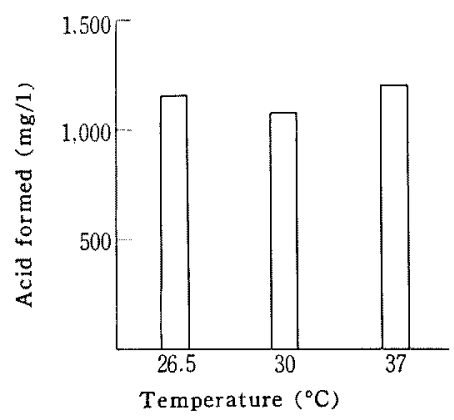

FIG. 7. Effect of Temperature on the Acid Production. 
Consequently, it is suggested that the control of the $\mathrm{pH}$ value and the agitation would be very important factors to improve the production of the acid from $p$-cymene.

The microbial transformation of $p$-cymene to cumic acid was reported by Davis and Raymond. $^{8} \quad$ The work showed that cumic acid was produced during the growth of a Nocardia on $n$-alkane. It was not described whether the Nocardia grew on p-cymene or not.

Further investigations on the cumic acid formation from $p$-cymene, including reaction mechanisms, and on other aromatic hydrocarbon-utilizing microorganisms are in pro-

8) J.B. Davis and R. L. Raymond, Appl. Microbiol,, 9, 383 (1961). gress. The results will be shown elsewhere.

\section{SUMMARY}

1. Five strains were isolated from soil with the aromatic hydrocarbon substrates as a sole carbon source.

2. They were identified as closely resembling Pseudomonas desmolytica.

They produced cumic acid during the growth on p-cymene.

3. Addition of calcium carbonate and considerable agitation were favorable cultural conditions for the acid production.

Acknowledgement. Grateful acknowledgement is made to Dr. I. Takeda and Mr. S. Hayakawa for the taxonomical studies. 